\title{
Descartes the Doctor: Rationalism and Its Therapies
}

\section{Citation}

Shapin, Steven. 2000. Descartes the doctor: Rationalism and its therapies. British Journal for the History of Science 33(2): 131-154.

\section{Published Version}

http://dx.doi.org/10.1017/S000708749900391X

\section{Permanent link}

http://nrs.harvard.edu/urn-3:HUL.InstRepos:3219884

\section{Terms of Use}

This article was downloaded from Harvard University's DASH repository, and is made available under the terms and conditions applicable to Other Posted Material, as set forth at http:// nrs.harvard.edu/urn-3:HUL.InstRepos:dash.current.terms-of-use\#LAA

\section{Share Your Story}

The Harvard community has made this article openly available.

Please share how this access benefits you. Submit a story.

\section{Accessibility}




\title{
Descartes the doctor: rationalism and its therapies
}

STEVEN SHAPIN*

\begin{abstract}
During the Scientific Revolution one important gauge of the quality of reformed natural philosophical knowledge was its ability to produce a more effective medical practice. Indeed, it was sometimes thought that philosophers who pretended to possess new and more potent philosophical knowledge might display that possession in personal health and longevity. René Descartes repeatedly wrote that a better medical practice was a major aim of his philosophical enterprise. He said that he had made important strides towards achieving that aim and, on that basis, he offered practical medical advice to others and advertised the expectation that, taking his own advice, he would live a very long time. This paper describes what Cartesian medicine looked like in practice and what that practice owed to the power of modernist Reason.
\end{abstract}

\section{Philosophy and its medical point}

There are four questions that have historically been put to philosophers and intellectuals that, so to speak, call them to task. 'If you're so smart, why aren't you good?' That is a Greek question, presuming that the goal of intellectual enquiry is personal virtue, and that the presence or absence of virtue in philosophers is a legitimate test of the knowledge they profess. 'If you're so smart, why aren't you happy?' That is a Greek question too, and a related one: it supposes that wisdom should delight, either because it issues in a better manner of living in the world or because its attainment fulfils a basic human longing. ${ }^{1}$ Then there is 'if you're so smart, why aren't you rich?'. That is what has been called 'the American question', though versions of it can be traced at least as far back as Francis Bacon. ${ }^{2}$ Here the presumption is that true knowledge is materially useful knowledge, and that individual or collective wealth is a reliable sign that genuine knowledge is at your disposal. ${ }^{3}$

\footnotetext{
* Department of Sociology, University of California, San Diego, La Jolla, CA 92093-0533, USA. For critical comments on earlier versions of this paper I thank Harold Cook, Peter Dear, Charles Rosenberg and the anonymous referees for this journal.

1 For a better manner of living in the world as a legitimate test of philosophical knowledge, see e.g. A. Nehamas, The Art of Living: Socratic Reflections from Plato to Foucault, Berkeley, CA, 1998; P. Hadot, Philosophy as a Way of Life: Spiritual Exercises from Socrates to Foucault, (trans. M. Chase, ed. A. I. Davidson), Oxford, 1995; and J. Cottingham, Philosophy and the Good Life: Reason and the Passions in Greek, Cartesian and Psychoanalytic Ethics, Cambridge, 1998.

2 D. N. McCloskey, If You're So Smart: The Narrative of Economic Expertise, Chicago, 1990.

3 All three of these 'test-questions' should be reasonably familiar to modern historians of ideas: the first and second through the work of such modern 'virtue theorists' as Martha Nussbaum and Alasdair MacIntyre; the third through historical studies of science-technology relations and of the rhetoric used to legitimate the place of science in mercantile societies.
} 
The fourth - formally, perhaps, a version of the second and third - is none the less distinct in its cultural framing and consequences. It is far less familiar than the first three, yet, I want to show, it was quite important in the early modern period as a way of advertising and gauging the quality of philosophical knowledge. This question was 'if you're so smart, how come you're sick ?', or - a variant - 'how come you died?', or, less ambitiously, 'how come you didn't live to a hundred-and-twenty?'.

Life-and-death matters matter. They matter to every-person and they matter to the learned person as every-person, since even Francis Bacon and René Descartes had vulnerable and, as it disappointingly turned out, mortal bodies about which they cared a great deal: viewed at times as instruments to their extraordinary souls, and at other times just as everybody else views their bodies, wishing that they would be less painful, more serviceable and more durable. That is one - blindingly obvious - reason why the ability to prevent and cure disease, to alleviate suffering and to extend human life has recurrently been used as a public test of the truth and power of philosophic and scientific systems, and why the learned too might share in that public assessment. ${ }^{4}$

However, there were reasons particular to the learned classes, and more particular to the great philosophical modernizers of the seventeenth century, why medicine mattered, even to those who were not themselves physicians. In general terms, it was bound to matter because of the close but contested relationship that has historically obtained between natural philosophy and the science of medicine and, through the science, the art of medicine. For Aristotelians and Galenists, knowledge of the hidden make-up and workings of the human body was wholly integrated within an overall philosophy of nature. The humours and the temperaments were just a part of the same system of elements and qualities that allowed philosophers to explain what the natural world was made of and why inanimate bodies moved as they did. For Aristotle, Galen and their followers 'medicine was the philosophy of the body', or, put another way, medicine was philosophy in action, put to the test. ${ }^{5}$ And so it remained for both Aristotelians and their critics in the early modern period.

Ars longa vita brevis - that is Hippocratic aphorism number one - but it did not matter how long you had to learn the art of medicine if that art was not securely founded on good philosophical principles. Early modern Aristotelians and Galenists, on the whole, considered that medical art was so founded, and that, correcting for the complexity of the human-environment transactions that made for individual health and disease, and for the intractability of patients' behaviour (even when expertly advised), medical practice did pretty well. And the fact - as they reckoned things - that it did pretty well was powerful testimony to the validity of medicine's philosophical foundations as well as to individual practitioners' skill. ${ }^{6}$

4 Of course, other conceptions of philosophy, e.g. Epicurean and Stoic, did not run this rule over knowledge: the purpose of philosophy was to console and to reconcile people to their inevitable fate.

5 See O. Temkin, Hippocrates in the World of Pagans and Christians, Baltimore, 1991, 8-9; idem, The Double Face of Janus and Other Essays in the History of Medicine, Baltimore 1977, 187-8.

6 There is no special epistemological problem associated with recognizing therapeutic 'success' in pre-modern medicine. From within a modernist and realist perspective, it is not difficult to identify pre-modern practices that 'worked' and plausible reasons that might save cherished intellectual principles when interventions 'did not 
However, if you were a seventeenth-century modernizing and mechanizing critic of traditional natural philosophy, you tended to take a very different view of the matter. ${ }^{7}$ Aristotelian natural philosophy was no good - unintelligible, absurd, vacuous - and any practice that was informed by that philosophy was itself likely to be no good. Claims to medical efficacy by Aristotelians and Galenists were deemed largely bogus. Thomas Hobbes was exceptional among the great seventeenth-century philosophical moderns in not developing a frontal assault on the state of medical knowledge and practice, though, to be sure, his explicit applause of the current state of medical knowledge was mainly a rhetorical vehicle to appropriate William Harvey for the mechanical cause and to ironically imply that the London physicians were not as Harveian as they ought rationally to be. ${ }^{8}$

In the main, the rest of the great modernizers took a very dim view of contemporary medicine. They said that contemporary medicine was just that kind of practice and belief that was largely false, mainly barren and, accordingly, in need of systematic reform. Only when medicine was put on solid natural philosophical foundations would it be of genuine use in healing, alleviating suffering and extending life. The precise nature of their criticisms differed, but their drift was consistent: we the moderns have reformed natural philosophical knowledge, and a reliable sign and legitimate test of our reformed natural philosophy will be not just a better science of medicine but a vastly more powerful system of medical practice. Why not be your own physician when existing medicine was so faulty and when you possessed the philosophical means for its reform ? ${ }^{9}$ Moreover, and perhaps

work': see, for example, E. H. Ackerknecht, Medicine and Ethnology: Selected Essays (ed. H. H. Walser and H. M. Koelbing), Baltimore, 1971, 120-34. When that realism is supplemented by a symbolic and cultural framework, 'working' is recognized as dramatically visible - as when purgatives, emetics and carminatives visibly, and sometimes spectacularly, 'worked' on the body: see C. E. Rosenberg, 'The therapeutic revolution: medicine, meaning, and social change in nineteenth-century America', Perspectives in Biology and Medicine (1977), 20, 485-506 (reprinted in idem, Explaining Epidemics and Other Studies in the History of Medicine [Cambridge, 1992], 9-31); and, for sociological sensibilities towards knowledge and its efficacy, see M. J. Mulkay, 'Knowledge and utility: implications for the sociology of knowledge', Social Studies of Science (1977), 9, 63-80.

7 For an entry into the large secondary literature on medicine and natural philosophy in the Scientific Revolution, see the fine essay by H. J. Cook, 'The new philosophy and medicine in seventeenth-century England', in D. C. Lindberg and R. S. Westman (eds.), Reappraisals of the Scientific Revolution, Cambridge, 1990, 397-436; also idem, 'Physicians and the new philosophy: Henry Stubbe and the virtuosi-physicians', in R. French and A. Wear (eds.), The Medical Revolution of the Seventeenth Century, Cambridge, 1989, 246-71; T. M. Brown, 'The College of Physicians and the acceptance of iatro-mechanism in England, 1665-1695', Bulletin of the History of Medicine (1970), 44, 12-30; idem, 'Physiology and the mechanical philosophy in mid-seventeenth-century England', ibid. (1977), 51, 25-54.

8 The 'Epistle dedicatory' to Hobbes's 'De corpore' (in The English Works of Thomas Hobbes (ed. Sir W. Molesworth), 11 vols., London, 1839-45, i), referred (p. viii) to 'the science of man's body' as 'the most profitable part of natural science', but specified that this science was 'first discovered' by Harvey. That science, Hobbes continued (p. xi), has been advanced in our times 'by the wit and industry of physicians, the only true natural philosophers, especially of our most learned men of the College of Physicians in London'. Hobbes had very little to say about medicine and it is not included in his map of the branches of philosophy in Chapter 9 of Leviathan, (ed. C. B. Macpherson), Harmondsworth, 1968 (originally published 1651), 149. For the significance of this omission, see Tom Sorell, 'Hobbes's scheme of the sciences', in idem, (ed.), The Cambridge Companion to Hobbes, Cambridge, 1996, 45-61, 52-4. For scattered remarks on Hobbes's diet and regimen of health, see A. A. Rogow, Thomas Hobbes: Radical in the Service of Reaction, New York, 1986, 224-6.

9 Of course, as in antiquity, while those early moderns able to afford their services did employ professional physicians, the practice of diagnosing and treating oneself was common. 
owing to the intense individualism of modernizing philosophical culture, thinkers' personal states of health and the lengths of their individual lives were sometimes used to gauge the goodness of their philosophical knowledge - both by themselves and by their supporters and critics.

The range of medical promissory notes issued by modernizers is one of the fascinating byways of the Scientific Revolution, though, from presentist points of view, the notes do not make for edifying reading: they look more like testaments to human folly than to the power of reason. Nevertheless, from an impeccably historicist point of view there are inducements to further consider these medical promises, for they offer an intriguing and perspicuous way of reconfronting and reframing some long-standing questions about the relations between theory and practice, and between tradition and change in the history of culture and of technique. What did it look like when modern philosophic reason in its purest and most rigorous forms became its own physician?

Francis Bacon offered wide-ranging criticisms of the state of medical science and art. 'Medicine', he wrote, 'is a science which hath been... more professed than laboured, and yet more laboured than advanced; the labour having been, in my judgment, rather in a circle than in progression'. Unless medicine were refounded upon a purified register of natural fact and a proper philosophy of nature, we could never hope for the effective treatment of disease or the prolongation of life: 'the science of medicine, if it be destituted and forsaken by natural philosophy, it is not much better than an empirical practice'. ${ }^{10}$ Medical practice lacked both evidential discipline and philosophical system. But were it to achieve discipline and system, what benefits might humankind expect? The 'prolongation of life', Bacon wrote, is the 'most noble' of all the parts of medicine, and he wrote extensively about how vast extension of human life might be achieved. ${ }^{11}$

Robert Boyle was deeply concerned with medical therapeutics throughout his life, and his advocacy of pharmaceutical 'specifics' was persistently framed and rationalized in terms of his version of corpuscular natural philosophy. "The physician borrows his principles of the naturalist', Boyle wrote, so he should borrow only the best. ${ }^{12}$ If you

10 Francis Bacon, 'The advancement of learning [Books I-II]', in The Philosophical Works of Francis Bacon, (ed. J. Spedding, R. L. Ellis and D. D. Heath), 5 ivols., London, 1857-8, iii, 253-491, 367, 373.

11 Francis Bacon, 'Of the dignity and advancement of learning, Book IV', in idem, Philosophical Works, op. cit. (10), iv, 372-404, 390; idem, 'The history of life and death', ibid., v, 213-335. See also Graham Rees's introductory essay to his edition of Bacon's De vijs mortis: Bacon, Philosophical Studies c. 1611-c. 1619, (ed. G. Rees), Oxford, 1996, pp. xvii-cx. For documentation of seventeenth-century English medical concern with the prolongation of life, see C. Webster, The Great Instauration: Science, Medicine and Reform 1626-1660, London, $1975,246-323$.

12 Robert Boyle, 'Usefulness of experimental natural philosophy', in idem, The Works of the Honourable Robert Boyle, (ed. Thomas Birch), 2nd edn., 6 vols., London, 1772, ii, 1-246, 66; see also 185-6:

it is scarce to be expected, that till men have a better knowledge of the principles of natural philosophy, ... it is hard to arrive at a more comprehensive theory of the various possible causes of diseases, and of the contrivance and uses of the parts of the body, the method which supposes this knowledge should be other than in many things defective, and in some erroneous.

See also ibid., 199, quoting Celsus: 'The contemplation of nature, though it maketh not a physician, yet it fits him to learn physick.' Boyle went on: 'A deeper insight into nature may enable men to apply the physiological discoveries made by it (though some more immediately, and some less directly) to the advancement and 
understood the hidden textures of matter, you would rightly grasp how drugs worked and how to select specific drugs that targeted particular illnesses and conditions. He supposed that he knew that better than did the physicians, and, accordingly, that he was more effective than they in treating both his own and others' diseases. For humours, substitute corpuscular textures and mechanisms: 'I think the physician... is to look on his patient's body, as an engine, that is out of order, but yet is so constituted, that, by his concurrence with the endeavours, or rather tendencies, of the parts of the automaton itself, it may be brought to a better state. ${ }^{13}$ It was commonly said that the Draconian laws 'were written in blood'; in Boyle's view this would be more accurately said of certain Hippocratic aphorisms, which, slavishly followed by contemporary physicians, cost the lives of countless patients. Systematic reform in natural history and natural philosophy will allow us to do better: 'there may be unthought of methods found, whereby, by ways different from those formerly used by physicians, a man may be much assisted in the whole manner of ordering himself, so as to preserve health, and to foresee and prevent the approach of many distempers'. ${ }^{14}$

\section{Infallible demonstration: Descartes's medical project}

Descartes's vision of the practical medical goods that would certainly be delivered to those possessed of right philosophical reason was more clear, coherent and ambitious than that of any other seventeenth-century intellectual modernizer. His vision was philosophically systematic and his commitment was lifelong. The Discourse on Method of 1637 announced that a renovated philosophy would make us 'as it were, the lords and masters of nature'. This mastery would, of course, be desirable 'for the invention of innumerable devices which would facilitate our enjoyment of the fruits of the earth and all the goods we find there, but also, and most importantly, for the maintenance of health'. Medicine 'as currently practised does not contain much of significant use', and most honest medical practitioners would freely acknowledge the disproportion between what we now know and what remains to be known. But, were medicine to be refounded on proper philosophical principles, 'we might free ourselves from innumerable diseases, both of the body and the mind, and perhaps even from the infirmity of old age'. ${ }^{15}$ Descartes publicly committed

improvement of physick.' Also ibid., 201, on 'the ineffectualness of our vulgar medicines, not only Galenical, but chymical'; and see M. Hunter, 'Boyle versus the Galenists: a suppressed critique of seventeenth-century medical practice and its significance', Medical History (1997), 41, 322-61.

13 Boyle's therapeutic activism sat alongside considerable stress on the curative power of nature: see B. B. Kaplan, 'Divulging of Useful Truths in Physick': The Medical Agenda of Robert Boyle, Baltimore, 1993, especially Chapter 5. What Boyle called the body's 'strainers' (e.g. the liver, spleen and kidneys) can alter a medicine's corpuscular texture or recombine it with other corpuscles, thus admitting it to certain bodily sites and not others. Or the specific medicine might itself 'restore the strainers to their right tone and texture' (Boyle, op. cit. (12), 192). Boyle was sceptical of Paracelsian and Helmontian talk of a 'universal medicine' (ibid., 196-7).

14 Boyle, op. cit. (12), 65, 112.

15 René Descartes, Discourse on the Method, published in The Philosophical Writings of Descartes (hereafter PWD), (trans. J. Cottingham, R. Stoothoff and D. Murdoch), 3 vols., Cambridge, 1985-91, i, 111-51, 142-3. Note also that Descartes claimed that medicine had the capacity to make 'men in general wiser and more skilful' since 
himself to achieving those ends, and even announced that he had already discovered a method that would 'inevitably' lead him to such practical knowledge, unless, he added, without evident irony, 'prevented by the brevity of life'. The essay concluded with Descartes's resolution 'to devote the rest of my life to nothing other than trying to acquire some knowledge of nature from which we may derive rules of medicine which are more reliable than those we have had up till now'. ${ }^{16}$

Descartes came from a medical family - his paternal and maternal grandfathers were both physicians - and it is possible that he studied medicine at Poitiers after he had finished at La Flèche. ${ }^{17}$ In 1645 he told the Earl of Newcastle that 'the preservation of health has always been the principal end of my studies, and I do not doubt that it is possible to acquire much information about medicine which has hitherto been unknown' ${ }^{18}$ And there is much evidence that Descartes's theoretical and practical medical concerns did arise very early in his philosophical career. One of his first biographers traced Descartes's formulation of medical goals back to 1629 , when 'not being able to forget the End and Scope of his Philosophy, which was only the benefit of Mankind, he seriously undertook the Study of Physick... He imagined that nothing was more capable to produce the temporal Felicity of this World... [and] he thought it necessary to find out some way or other to secure Humane Body from Evils that might disturb its Health'. ${ }^{19}$

By 1630 , in any event, Descartes was in earnest pursuit of a practical therapeutic system founded on his rational reform of philosophy. In that year Marin Mersenne told Descartes that he was suffering from the skin disease erysipelas. Descartes sympathized and told Mersenne 'to look after' himself, 'at least until I know whether it is possible to discover a system of medicine which is founded on infallible demonstrations, which is what I am investigating at present '. ${ }^{20}$ Three months later Descartes still had not discovered such a system, but announced to Mersenne that he was then studying chemistry and anatomy in the hope that these fundamental studies would help 'find some cure for your erysipelas'. ${ }^{21}$ Nine years passed, and still no medical system based on 'infallible demonstrations', but

'the mind depends so much on the temperament and disposition of the bodily organs', so that one could imagine a virtuous cycle in which the practitioners of reformed medicine would become more clever and, hence, capable of making even more discoveries, which would in turn make them cleverer still. See also G. Rodis-Lewis, Descartes: His Life and Thought (trans. J. M. Todd), Ithaca, 1998, 127-8; and Temkin, Hippocrates, op. cit. (5), 13 (for the ancient view that 'human intelligence could be changed by diet').

16 Descartes, Discourse, op. cit. (15), 143, 151. Descartes's medical promises, and especially his views about the extension of human life, are briefly sketched in G. J. Gruman, A History of Ideas about the Prolongation of Life, New York, 1977 (originally published 1966), 77-80.

17 Descartes, Discourse, op. cit. (15), 113; S. Gaukroger, Descartes: An Intellectual Biography, Oxford, 1995, 20, 64 (generally endorsing the idea that Descartes formally studied medicine), and Rodis-Lewis, op. cit. (15), pp. vii, ix, 1-2, 18-19; and idem, 'Descartes' life and the development of his philosophy', in J. Cottingham (ed.), The Cambridge Companion to Descartes, Cambridge, 1992, 21-57, 28-9 (judging it unlikely that Descartes did study medicine and disputing traditional early datings of his medical interests).

18 Letter from Descartes to Newcastle, October 1645, in PWD iii, 275 (my emphasis); see also R. B. Carter, Descartes' Medical Philosophy: The Organic Solution to the Mind-Body Problem, Baltimore, 1983, 31.

19 Adrien Baillet, The Life of Monsieur Des Cartes... Translated from the French by S. R., London, 1693 (originally published 1691), 79-80.

20 Letter from Descartes to Mersenne, January 1630, in PWD, iii, 17; Baillet, op. cit. (19), 81; G. A. Lindeboom, Descartes and Medicine, Amsterdam, 1979, 43.

21 Letter from Descartes to Mersenne, 15 April 1630, in PWD, iii, 21. 
Descartes was unfazed, convinced that he was on the right lines, having supplemented theory with the dissection of many animal bodies:

I have spent much time on dissection during the last eleven years, and I doubt whether there is any doctor who has made such detailed observations as I. But I have found nothing whose formation seems inexplicable by natural causes. I can explain it all in detail, just as in my Meteorology I explained the origin of a grain of salt or a crystal of snow. ${ }^{22}$

The Description of the Human Body (composed in the winter of 1647-8 and published posthumously) began with the Delphic injunction to 'know ourselves'. But the benefits accruing from that self-knowledge were here identified as specifically medical: 'I believe that we would have been able to find many very reliable rules, both for curing illness and for preventing it, and even for slowing down the ageing process, if only we had spent enough effort on getting to know the nature of our body'. ${ }^{23}$ Questioned two years before his death about the Discourse's hints concerning the philosophically mediated prolongation of human life, Descartes's confidence remained unshaken: 'it should not be doubted that human life could be prolonged, if we knew the appropriate art. For since our knowledge of the appropriate art enables us to increase and prolong the life of plants and such like, why should it not be the same with man?'. ${ }^{24}$ So there is Descartes's own testimony, repeated throughout his life and in a variety of settings, that medical prophylaxis, therapeutics and the extension of human life were central goals - even the most cherished goals - of his philosophical reform programme.

How did Descartes think these goals could be achieved? And what did he see as the relationship between proper philosophy and practical healing? The Preface to the French edition of the Principles of Philosophy (1647) introduced the celebrated metaphor of philosophy as a tree: 'The roots are metaphysics, the trunk is physics, and the branches emerging from the trunk are all the other sciences, which may be reduced to three principal ones, namely medicine, mechanics and morals. ${ }^{25}$ This is how things should be, and,

22 Letter from Descartes to Mersenne, 20 February 1639, in PWD, iii, 134. On Descartes's dissections, see also Descartes to Mersenne, early June 1637, ibid., 59; Baillet, op. cit. (19), 80; T. S. Hall, 'Foreword', in Descartes, Treatise of Man, (ed. and trans. Hall), Cambridge, Mass., 1972, pp. xii-xiii.

23 Descartes, Description of the Human Body, in PWD, i, 313-24, 314.

24 J. Cottingham (ed. and trans.), Descartes' Conversations with Burman, Oxford, 1976, 50. Descartes refused (ibid.) to be drawn on the question of whether 'man was immortal before the Fall'. Although both the fact and the explanation for Edenic immortality was much debated by Renaissance and early modern physicians, Descartes's judgement was that this was 'not a question for the philosopher, but must be left to the theologians'. Frans Burman was a twenty-year-old student who interviewed Descartes in April 1648 at the philosopher's home in Egmond. See also Lindeboom, op. cit. (20), 96-7. The 'Preface' to The Passions of the Soul noted that God had undoubtedly provided people 'with all things necessary ... to be preserved in perfect health to an extreme old age': what was lacking was the knowledge of what these necessary things were: 'Preface' to Descartes, The Passions of the Soul, (ed. and trans. S. Voss), Indianapolis, 1989 (originally published 1649), 7. For the editor's view that this 'Preface' was probably written by Descartes himself, see ibid., 1, n. 1.

25 Descartes, Principles of Philosophy (extracts), in PWD, i, 179-291, 186. As Richard Carter puts it, for Descartes 'physics deals with the general body out of which particular bodies are formed; medicine deals with particular, mortal bodies that are alive and that have souls united to them': Carter, op. cit. (8), 31. Descartes's well-known stipulation - both in the Principles and in the Treatise of Man - that he was giving an account not of real but of imaginary human bodies did not, in his estimation here, diminish its significance for medical practice. The characteristics he attributed to these imaginary bodies were supposed to be 'such as to correspond accurately with all the phenomena of nature'. And this 'will indeed be sufficient for application in ordinary life, 
following Cartesian reform, how they would be. But given the poor state of contemporary physics, it was deemed fortunate that matters were now otherwise arranged. So in The Passions of the Soul Descartes (or, at least, a close associate) wrote that medicine, 'as it's practised today by the most learned and prudent in the art', does not depend on physics: 'they are content to follow the maxims or rules which long experience has taught, and are not so scornful of human life as to rest their judgments, on which it often depends, on the uncertain reasonings of Scholastic Philosophy'. ${ }^{26}$

In this connection Roger French has noted how Descartes was bidding to fill a space in the university curriculum then securely occupied by Aristotle's Organon (or body of logical writings). One of the characteristics of this space, French writes,

was that the arts course naturally led on (for those who wished to follow that path) to medicine. Not only did the arts course generally end with one of the more biological of the Aristotelian physical works, but the whole theory of medicine was based on the principles of Aristotle's natural philosophy: 'where the philosopher finishes, there begins the physician' was a common doctor's defence of his own subject.

So if Descartes was going to supplant Aristotle in the university curriculum, a Cartesian medicine was required. It was institutionally and culturally natural for Descartes to associate the new philosophy with a new and vastly more powerful medicine. ${ }^{27}$

Descartes's mechanistic physiology was formally elaborated in a number of tracts - the Discourse, the Treatise of Man (composed 1629-33), the Description of the Human Body and The Passions of the Soul (1649). The heart powered the animal machine. Its motion was the source of all other bodily motions, and its natural heat was the natural source of those motions. The heat of the heart rarefied the blood, 'and this alone... is the cause of the heart's movement'. ${ }^{28}$ That is why the explanation of the heart's motions was offered as the key exemplar of Descartes's mechanical philosophy in Part V of the Discourse. ${ }^{29}$ 'The cardinal tenet', as T. S. Hall puts it, of Cartesian physiology is the assumption that motion is transferred from part to part by contact, and the original source of bodily motion is the heat of the heart. ${ }^{30}$ Having sketched his physiological system in the Description of the Human Body, Descartes declared that 'this will enable us to make better use both of

since medicine and mechanics... are directed only towards items that can be perceived with the senses' (Descartes, Principles, 289 [Part IV, section 204]). That is to say, philosophically informed medical interventions might work even if the philosophically posited underlying causal structures were not the real ones. Later I shall note how Descartes came to qualify that optimism.

26 'Preface' to Descartes, Passions, op. cit. (24), 7.

27 R. French, 'Harvey in Holland: circulation and the Calvinists', in French and Wear (eds.), op. cit. (7), 46-86, 53-4; also Baillet, op. cit. (19), 121-2, 127-8.

28 Descartes, Description, op. cit. (23), 319.

29 And also how Descartes distinguished his cardiac physiology from Harvey's. See also Descartes, Passions, op. cit. (24), 21-2; idem, Description, op. cit. (23), Part II. Also T. S. Hall, 'The physiology of Descartes', in Descartes, Treatise, op. cit. (22), pp. xxvi-xxxiii; idem, History of General Physiology, 2 vols., Chicago, 1975, i, 250-64; G. Hatfield, 'Descartes' physiology and its relation to his psychology', in J. Cottingham (ed.), op. cit. (17), 335-70; Gaukroger, op. cit. (17), 269-76. For the physiological writings of Descartes's major medical disciple, the Utrecht professor of theoretical medicine Henricus Regius, see T. Verbeek, Descartes and the Dutch: Early Reactions to Cartesian Philosophy, 1637-1650, Carbondale, IL, 1992, Chapter 2.

30 French, op. cit. (27), 50-1; T. S. Hall, 'First French edition: synopsis of contents', in Descartes, Treatise, op. cit. (22), p. xxxvi. 
body and of soul and to cure or prevent the maladies of both'. And, given the significance of cardiac theory in Descartes's physiology, he insisted that without accurate knowledge of 'the true cause of the heart's motion' - which he considered he now had - 'it is impossible to know anything which relates to the theory of medicine'. ${ }^{31}$

The gap between the theory of medicine and its practical realization in both hygiene and therapeutics was only occasionally bridged in Descartes's writings. That is, Descartes rarely spelled out exactly how it was that certain dietetic practices or therapeutic interventions worked in mechanical and corpuscular terms or how proper philosophical principles led to new and uniquely effective changes in medical art. ${ }^{32}$ Despite this largely unbridged gap between theory and practice, there is much evidence that Descartes thought his philosophical achievements did put him in a position to understand and to manage his own body better than the physicians and to offer advice to friends and colleagues that was superior to available professional alternatives. I want first to consider how Descartes acted as his own physician and then to detail and interpret the range of concrete dietetic and therapeutic advice he gave his associates.

\section{Descartes his own physician}

At least twice in his life Descartes explicitly endorsed ancient counsel that one be one's own physician. The wise man (the argument went), taking the advice of Apollo's oracle, ought indeed, after a period of time, to come to know himself better than any physician possibly could. This is what he told the Earl of Newcastle in 1645:

I share the opinion of Tiberius, who was inclined to think that everyone over thirty had enough experience of what was harmful or beneficial to be his own doctor. Indeed it seems to me that anybody who has any intelligence, and who is willing to pay a little attention to his health, can better observe what is beneficial to it than the most learned doctors. ${ }^{33}$

Three years later he repeated the same sentiments to Frans Burman when the young student asked him what foods one ought to eat and how one ought to eat them. We become our own experts on such matters: 'So, as Tiberius Caesar said (or Cato, I think), no one who has reached the age of thirty should need a doctor, since at that age he is quite able to know himself through experience what is good or bad for him, and so be his own doctor. ${ }^{34}$ Here Descartes was not apparently advertising the special virtues of his new philosophical system; he was merely pointing out that if you were a wise and attentive man, then medical expertise deserved no deference, and noting that he himself was such a man.

Descartes's self-monitoring began at an early age. A sickly and delicate child, he was born (so he later told Princess Elizabeth of Bohemia) with 'a dry cough and a pale colour' which he believed he inherited from his mother and which remained with him until he was

31 Descartes, Description, op. cit. (23), 316, 319.

32 The most important site of such discussion is Descartes's late writings on the passions of the soul (to be treated below).

33 Letter from Descartes to Newcastle, October 1645, in PWD, iii, 275-6.

34 Descartes, Conversations, op. cit. (24), 51. The source is in fact Suetonius' life of Tiberius. See also Baillet, op. cit. (19), 260 (who put Descartes's age at 19 or 20 when he came to that opinion); Lindeboom, op. cit. (20), 94-5; Rodis-Lewis, op. cit. (15), 19. 
twenty, 'so that all the doctors who saw me up to that time gave it as their verdict that I would die young ${ }^{35}$ As a child and young man he was used to taking special care of himself. At La Flèche he was permitted to lie in bed until quite late in the morning, partly owing to weakness, partly because he recognized the special virtue of post-waking bed-time for deep meditations. ${ }^{36}$ Descartes liked spending time in bed: in 1631 he was still getting a solid ten hours of (dreamless) sleep a night, and he recommended his friends to do likewise. ${ }^{37}$ Deep contemplations were hard work, and he was careful to ration philosophizing-time to just a few fully rested hours a day. ${ }^{38}$

Descartes's already acute self-monitoring seems to have been sharpened by his mid-life crisis, when, after turning forty, he began to notice 'the gray hairs that are coming in a rush': he did not want 'to study anything any more except the means of postponing' old age. ${ }^{39} \mathrm{He}$ told Constantijn Huygens that 'I have never taken greater care in looking after myself than I am doing at the moment'. Yet he was in an optimistic frame of mind: he had once believed that he was built to last only thirty or forty years, but now he saw the prospect of living 'a hundred years or more' if only he could produce that infallible system of medicine he had told Mersenne about seven years before:

I think I see with certainty that if only we guard ourselves against certain errors which we are in the habit of making in the way we live, we shall be able to reach without further inventions a much longer and happier old age than we otherwise would. But since I need more time and more observational data if I am to investigate everything relevant to this topic, I am now working on a compendium of medicine, basing it partly on my reading and partly on my own reasoning. I hope to be able to use this as a provisional means of obtaining from nature a stay of execution, and of being better able from now on to carry out my plan. ${ }^{40}$

Mersenne said that people were worried about Descartes's health, but Descartes told them not to be:

35 Letter from Descartes to Princess Elizabeth, May or June 1645, in PWD, iii, 251. His mother's disease was caused, he said, by 'distress' (déplaisirs). See also Descartes to Mersenne, 30 July 1640, ibid., 148 (for the maternal role in inheritance), and Baillet, op. cit. (19), 3-5, 260.

36 Baillet, op. cit (19), 14, 66; see also P. Dear, 'A mechanical microcosm : bodily passions, good manners, and Cartesian mechanism', in C. Lawrence and S. Shapin (eds.), Science Incarnate: Historical Embodiments of Natural Knowledge, Chicago, 1998, 51-82, 54-5.

37 Letter from Descartes to Jean-Louis Guez de Balzac, 5 April 1631, in PWD, iii, 30; Descartes to Elizabeth, 1 September 1645, ibid., 263; Baillet, op. cit. (19), 259 (who said that Descartes commonly spent as much as twelve hours a day in bed).

38 Letter from Descartes to Princess Elizabeth, 28 June 1643, in PWD, iii, 227; also Baillet, op. cit. (19), 35-6: high speculations 'threw his mind into such violent Agitations... He wearied it out to that degree that his brain took fire, and he falls into a spice of enthusiasm'. For the contemporary charge that Descartes was an 'enthusiast', see M. Heyd, 'Be Sober and Reasonable': The Critique of Enthusiasm in the Seventeenth and Eighteenth Centuries, Leiden, 1995, Chapter 4, especially 116-17. For Henry More, Anne Conway and the dietetic management of philosophical heat, see S. Shapin, "The philosopher and the chicken: on the dietetics of disembodied knowledge', in Lawrence and Shapin (eds.), op. cit. (36), 21-50, 38-40; and, for treatment of pertinent aspects of the relationship between the passions and enthusiasm, see A. Johns, 'The physiology of reading and the anatomy of enthusiasm', in O. P. Grell and A. Cunningham (eds.), Religio Medici: Medicine and Religion in Seventeenth-Century England, Aldershot, 1996, 136-70.

39 Letter from Descartes to Constantijn Huygens, 5 October 1637, in Oeuvres de Descartes (ed. C. Adam and P. Tannery), 11 vols., Paris, 1964-76, ii, 434-5; also Baillet, op. cit. (19), 122, 258.

40 Letter from Descartes to Huygens, 4 December 1637, in PWD, iii, 76; see also Gaukroger, op. cit. (17), $332-3$. 
by the grace of God, during the last thirty years I have not had any illness which could properly be called serious. Over the years I have lost that warmth of the liver which in earlier years attracted me to the army; and I no longer profess to be anything but a coward. Moreover, I have acquired some little knowledge of medicine, and I feel very well, and look after myself with as much care as a rich man with gout. For these reasons, I am inclined to think that I am now further from death than I ever was in my youth. ${ }^{41}$

Two years later he still saw physical signs that he would live a very long time: he told Huygens that 'my teeth are still so firm and strong that I do not think I need fear death for another thirty years, unless it catches me unawares'. ${ }^{42}$

These claims were circulated throughout the learned community. Thus encouraged by the man himself, at least some commentators were prepared to assess Descartes's philosophy by his visible success or failure in acting as his own physician. In 1637 Huygens begged Descartes to write him just a few lines about 'the means to live longer than we now do', and later valued Descartes's judgement enough to consult him about a physician for the Stadtholder. ${ }^{43}$ And at some unknown date the visiting English philosopher Sir Kenelm Digby told Descartes that life was too short to waste time in 'bare speculations': if you really have reliable physiological knowledge, then the thing to do was to find practical 'ways and means to prolong' human life. Descartes evidently replied that he already had the matter in hand: while he (modestly) could not promise 'to render a man immortal... he was quite sure it was possible to lengthen out his life span to equal that of the Patriarchs', that is to say, up to almost a thousand years. ${ }^{44}$ The belief that Descartes was after the secret of living much longer, or even that he had already cracked that secret, was not uncommon. ${ }^{45}$ So it was a great shock to some of his friends when he died in Sweden, aged just 54. Descartes acted as his own physician even on his deathbed. He declined the ministrations of the Swedish court physicians, preferring his own preparation of tobaccoflavoured wine to bring up the phlegm. He resisted being bled and only submitted towards the end, 'in a great quantity, but to no purpose'. ${ }^{46}$

On hearing the news of Descartes's death, his friend the Abbé Claude Picot said that 'he would have sworn that it would have been impossible for Descartes to die at the age of 54, as he did; and that, without an external (étrangère) and violent cause as that which deranged his machine (dérégla sa machine) in Sweden, he would have lived five hundred years, after having found the art of living several centuries' ${ }^{27}$ Stories spread that Descartes

41 Letter from Descartes to Mersenne, 9 January 1637, in PWD, iii, 131; also Baillet, op. cit. (19), $23,260$. 42 Letter from Descartes to Huygens, 6 June 1639, in PWD, iii, 136.

43 Letter from Huygens to Descartes, 23 November 1637, in Oeuvres, op. cit. (39), i, 463; cf. Huygens to Descartes, 8 September 1637, ibid., 396-7; also Lindeboom, op. cit. (20), 44, 96.

44 Reported in Pierre Des Maizeaux's Life of St. Evremond (1728) and quoted in Descartes, Oeuvres, op. cit. (39), xi, 671; see also Gruman, op. cit. (16), 79.

45 See Descartes, Oeuvres, op. cit. (39), xi, 670-1; Adrien Baillet, La vie de Monsieur Des-Cartes, 2 vols., Paris, 1691, ii, 449-54.

46 Baillet, op. cit. (19), 252-3; idem, op. cit. (45), ii, 414-23.

47 Reported in Baillet, op. cit. (45), ii, 452-3; also Descartes, Oeuvres, op. cit. (39), ii, 671; and see Lindeboom, op. cit. (20), 95. Note that a disease - such as what we would now call pneumonia - that was precipitated by an alteration in regimen, or by exposure to extreme conditions, would then have been regarded as a 'violent' or 'external' cause of death. So Baillet said (op. cit. (19), 252) that Descartes's last illness was partly caused by 'the disorder of [his] regular way of living'. The general idea was that one's natural life span was the length 
had in fact been poisoned, and, if this tale were credited, then the cause would have been external and violent indeed. But in the main it was not believed. Most commentators seem to have been satisfied that he had died of a 'fiebure continue avec inflammation de poulmon', or 'une pleuresie', or, probably, in plain modern terms, pneumonia. ${ }^{48}$ His early death was taken, Lindeboom says, as 'a blow at the reliability of his philosophy'. When news of his death reached the Low Countries, a Flemish journal reported 'that in Sweden a fool had died who had claimed to be able to live as long as he liked'. ${ }^{49}$ Queen Christina, whose demands for philosophy lessons at five in the morning were the proximate cause of the fatal illness, even sneered, 'Ses oracles l'ont bien trompé'. ${ }^{50}$

\section{Descartes prescribes}

Throughout his adult life, Descartes offered friends and colleagues a stream of practical medical advice. Some of this advice was explicitly advertised to follow from his new philosophical principles, while other advice not so advertised might nevertheless have been informed by these principles. He did not ultimately deliver Mersenne the powerful medical system based on 'infallible demonstrations', but many years after that promise Descartes still felt himself in a position to tell Mersenne exactly how a mutual friend, Claude Clerselier, ought to be treated for epileptic fits. First, Descartes cautioned against blindly accepting physicians' recommendations that the patient be bled: 'they are great ones for bleeding in Paris, and I am afraid that when they see the benefits of one blood-letting, they will keep on with the treatment, which will greatly weaken the brain without improving his bodily health' ${ }^{51}$

Mersenne told him that Clerselier's condition began with a sort of gout in the toe, and Descartes replied that

if it is still not better, and he continues to have epileptic fits, I think it would be beneficial to make an incision right to the bone in the part of the toe where the trouble began, especially if he is known to have been injured in that area; there may be some infection still present which is the cause of the trouble, and it needs to be driven out before a cure can be effected.

As confident as he was of this advice, Descartes was reluctant to have it known that he was appearing in the person of a professional physician, 'interfering with medical consultations

of time one would live without the violent causes that shortened it artificially. The relationship recognized by the early moderns between disease and old age was, however, contested; some saw old age as a disease, others as a state that made one susceptible to disease. See, for representative discussion, Laurent Joubert, Popular Errors, (trans. G. D. de Rocher), Tuscaloosa, AL, 1989 (originally published 1579), 41-3; also M. D. Grmek, On Ageing and Old Age: Basic Problems and Historic Aspects of Gerontology and Geriatrics, Monographiae Biologicae, Vol. 5, No. 2, The Hague, 1958, especially 5-10.

48 Hector-Pierre Chanut to Princess Elizabeth, 19 February 1650, in Descartes, Oeuvres, op. cit. (39), v , 471; Samuel Sorbière to Pierre Petit, 20 February 1657, in ibid., 485.

49 Extra ordinarisse Posttijdinghe (10 April 1650); quoted and translated in Lindeboom, op. cit. (20), 94.

50 Lindeboom, op. cit. (20), 94; Dear, op. cit. (36), 61-2. For the circumstances of, and stories about, Descartes's death, see especially Gaukroger, op. cit. (17), 415-17, and various sources assembled in Descartes, Oeuvres, op. cit. (39), v, 470-500.

51 Baillet, op. cit. (19), 260. Descartes rarely approved of phlebotomy - which he accounted 'extream dangerous to most People' - though, as noted, he did tolerate moderate bleeding in certain limited circumstances. 
... So if you think it right to pass on my suggestion to one of his doctors, please make sure that he is quite unaware that it comes from me'.52

In 1647 Descartes paid a call on the sickly young mathematician Blaise Pascal in Paris, Pascal having moved there from Rouen in order to consult physicians. Descartes wanted to speak to Pascal about the latter's vacuum experiments, but, seeing how weak he looked, Descartes volunteered some medical advice: a lot of bed-rest and a lot of soup (force bouillons).$^{53}$ Princess Elizabeth consulted Descartes about a range of medical conditions from the start of their correspondence in 1643. In December 1646 she wrote to Descartes about a swelling in her hands, for which court physicians had already been consulted. Descartes advised against accepting their remedies - above all phlebotomy - at least until spring, 'when the pores are more open and so the cause can be eliminated more readily'. And should the condition persist until spring, 'it will be easy to drive it away by taking some gentle purgatives or refreshing broths which contain nothing but known kitchenherbs, and by not eating food that is too salty or spicy'. Elizabeth was further warned against meddling with non-Galenical 'chemical remedies'. Since their corpuscular textures were precisely related to their physiological effects, it was vital that such drugs be prepared with much greater care than one could usually expect from chemists and apothecaries, 'for if you make the slightest change in preparing them, even when you think you are doing your best, you can wholly change their qualities, and make them into poisons rather than medicines'. ${ }^{54}$ These drugs should be used 'rarely and with great precautions' ${ }^{55}$ On the other hand, there was no reason to 'despise good remedies just because they are in common use': in its sorry current state medical expertise was likely to be more dangerous than common custom. ${ }^{56}$

He was similarly concerned about the composition of mineral waters and their exact medical effects. The waters of Spa were said to be all right - provided that they were taken at the right season - but the so-called miraculous spring at Hornhausen was likely to be dangerous because of its possible chemical composition:

There are many wretched people who broadcast its virtues, and are perhaps hired by those who hope to make a profit from it. For it is certain that there is no cure for all ills; but many people have made use of this spring, and those who have benefited from it speak well of it, while no one

52 Letter from Descartes to Mersenne, 23 November 1646, in PWD, iii, 301; Lindeboom, op. cit. (20), 44. Around the same time, in a case of nosebleed, Descartes warned against the use of wine, vinegar, mustard and saffron. A small amount of blood might be let, but care had to be taken to take blood from the foot on the same side of the body as the bleeding nostril: Descartes to [Boswell ?], [1646?], in Descartes, Oeuvres, op. cit. (39), iv, 694-700, 698-9; Lindeboom, op. cit. (20), 43-4.

53 Letter from Jacqueline Pascal to her sister Gilberte Périer, 25 September 1647, in Lettres, Opuscules et Mémoires de Madame Perier et de Jacqueline, sours de Pascal, et de Marguerite Perier, sa nièce (ed. M. P. Faugère), Paris, 1845, 309-12. Pascal suffered badly from dyspepsia and migraine, and, from around the time he met Descartes, probably from a kind of motor neuropathy. For an account of this momentous meeting - at which Descartes (as he later claimed) suggested the Puy-de-Dôme experiment - see Rodis-Lewis, op. cit. (15), 178-81; also E. T. Bell, Men of Mathematics, New York, 1937, 80.

54 Letter from Descartes to Princess Elizabeth, December 1646, in PWD, iii, 304-5; Baillet, op. cit. (19), 260.

55 Baillet, op. cit. (45), ii, 452. For notes on materia medica by Descartes, see 'Remedia, et vires medicamentorum', in Oeuvres, op. cit. (39), xi, 641-4; also idem, 'Excerpta anatomica', in ibid., 543-634, 606.

56 Letter from Descartes [to Alphonse Pollot], mid-January 1641, in PWD, iii, 168. 


\section{Steven Shapin}

mentions the others. However that may be, the purgative quality in one of the springs, and the white colour, softness and refreshing quality of the other, make me think that they pass through deposits of antimony or mercury, which are both bad drugs, especially mercury. That is why I would advise no one to drink from them. The acid and iron in the waters of Spa are much less to be feared; and because they diminish the spleen and chase away melancholy, I value them both. $^{57}$

\section{The dietetics of pure common sense}

The advice Descartes took for himself seems to have been broadly similar to that which he offered others. On the whole, Descartes's personal dietetics, regimen and therapeutics do not appear either radical or innovative. Descartes's dietetics were temperate in most respects, and he was sceptical about a whole range of heroic medical therapies which purported to do better than the healing powers of nature. Knowing yourself, and acting as your own physician, meant - for Tiberius, Descartes and very many early moderns - that you learned, over a long period of time, what foods agreed with you and what did not, what order and quantity they should be taken in, what manner of living, forms of exercise, patterns of sleeping, modes of emotional expression and restraint, and types of intellectual stimulation were best for your individual body. If you needed medicine, then you could call on a stock of personal experience, or even intuition, to judge what was required for your specific condition. That is to say, learning to be a prudent and effective gentleman meant that you fashioned yourself physiologically as well as culturally, and that you learned how best to manage the six 'non-naturals', not as a general and theoretical matter but as a particular, personal, and practical matter. ${ }^{58}$

'Our own experience', Descartes told young Burman, teaches us 'whether a food agrees with us or not, and hence we can always learn for the future whether or not we should have the same food again, and whether we should eat it in the same way and in the same order'. Even when we are ill, we should let our appetites be our guide. Every wise person knew

57 Letters from Descartes to Princess Elizabeth, May or June 1645, in PWD, iii, 250; 22 July 1645, in ibid., 255; October or November 1646, in ibid., 298. See in this connection L. W. B. Brockliss, 'The development of the spa in seventeenth-century France', in R. Porter (ed.), The Medical History of Waters and Spas, Medical History Supplement No. 10 (1990), 23-47.

58 It should go almost without saying that choice in such matters was available only to those classes who had the resources to choose. Medical advice on dietetics and regimen was therefore geared to the élite. On this point, see L. Edelstein, 'The dietetics of antiquity', in idem, Ancient Medicine: Selected Papers of Ludwig Edelstein (ed. O. Temkin and C. L. Temkin), Baltimore, 1967 (essay originally published 1931), 303-16, 305-6; A. Emch-Dériaz, 'The non-naturals made easy', in R. Porter (ed.), The Popularization of Medicine 1650-1850, London, 1992, 134-59, especially 135-6; and W. Coleman, 'Health and hygiene in the Encyclopédie: a medical doctrine for the bourgeoisie', Journal of the History of Medicine (1974), 29, 399-421, 399, 401. The usual list of early modern nonnaturals included: ambient air, diet (in the strict sense of meat and drink), sleeping and waking, exercise and rest, retentions and evacuations (including sexual release) and the passions of the mind. For debates over the Galenic sources of the doctrine and phrase, see L. J. Rather, "The "six things non-natural": a note on the origins and fate of a doctrine and a phrase', Clio Medica (1968), 3, 337-47; S. Jarcho, 'Galen's six non-naturals: a bibliographic note and translation', Bulletin of the History of Medicine (1970), 44, 372-7; P. Niebyl, 'The nonnaturals', ibid. (1971), 45, 486-92; J. J. Bylebyl, 'Galen on the non-natural causes of variation in the pulse', ibid. (1971), 45, 482-5. I deal extensively with early modern polite dietetics in S. Shapin, 'How to eat like a gentleman: dietetics and ethics in early modern England', in C. E. Rosenberg (ed.), Health and the Home, Baltimore, in press. 
this through experience, and it was only learned physicians who counselled otherwise: 'perhaps if doctors would only allow people the food and drink they frequently desire when they are ill, they would often be restored to health far more satisfactorily than they are by means of all those unpleasant medicines ${ }^{59}$ While Descartes himself was dietetically temperate, he did not make a fetish of his food. He was neither gluttonous nor abstemious. He was restrained in his consumptions, yet he was not one to fail in his obligations as a gentleman. As Baillet wrote,

His course of Diet was always uniform. Sobriety was natural to him. He drunk little Wine, and was sometimes a whole Month together without drinking a drop yet seeming very jocund and pleasant at table, his frugality not burthensome to his Company. He was neither nice nor difficult in the choice of his Victuals, and he has accustomed his Palat to every thing that was not prejudicial to the health of the Body. ${ }^{60}$

Descartes was no ascetic: 'He knew Nature must be supply'd'; he took moderate exercise; he counted bodily health 'the greatest Blessing in this life next to Virtue'; and he systematically explored the dependence of the mind upon the body. 'His judgment was, that it was good always to keep the Stomach and other Viscera a doing, as we do to Horses', and, while he was not a vegetarian, he did seem to commend a high-fibre diet, viz. 'Roots and Fruits, which he believed more proper to prolong the Life of Man, than the Flesh of Animals. ${ }^{61}$ Why should that which was good for the animal machine not be good for the human machine? So he told Burman that 'the best way of prolonging life, and the best method of keeping to a healthy diet, is to live and eat like animals, i.e. eat as much as we enjoy and relish, but no more'. ${ }^{62}$ His 'two grand Remedies' were 'his spare regular Diet, and moderation in his Exercise'. ${ }^{63}$

\section{Looking on the bright side of life: managing the passions}

Baillet went on to say that the remedy Descartes favoured even before moderate diet and exercise was the proper management of the emotions. ${ }^{64}$ And, indeed, by far the most pervasive medical advice met with in Descartes's writings, and the most explicitly reflectedupon advice, was the injunction to cheer up. Everyone who consulted him got the advice to cheer up; Descartes said he took it himself, to great effect; and he elaborated the physiological reasons for its efficacy in great detail. Cheering up appears as a

59 Descartes, Conversations, op. cit. (24), 51.

60 Baillet, op. cit. (19), 259. This was just the kind of thing that was commonly said of the dietetics of the early modern gentleman-philosopher. Indeed, it closely parallels Gilbert Burnet's funeral sermon preached over Robert Boyle's body in the year after Baillet wrote this account. It was a way of saying that the scholarly life had not 'spoiled' the virtues and manners of the civic gentleman, and, of course, this kind of dietetics was a way for the gentleman-philosopher to present himself as unspoiled by scholarly moroseness, melancholy or asceticism: Shapin, op. cit. (38), 37-8, and idem, op. cit. (58).

61 Baillet, op. cit. (19), 259-60.

62 Descartes, Conversations, op. cit. (24), 50; for his liking of vegetables from his own garden, see Baillet, op. cit. (45), ii, 450 .

63 Baillet, op. cit. (19), 260.

64 Baillet, op. cit. (19), 260. 
characteristically Cartesian remedy, and it connects Cartesian philosophical radicalism to medical tradition in a revealing way.

In 1644 Princess Elizabeth consulted Descartes about her upset stomach. Descartes, of course, recommended moderate diet and exercise, but especially drew her attention to the influence of the soul on the body. Believe that you are basically healthy and you will in general be healthy:

I know no thought more proper for preserving health than a strong conviction and firm belief that the architecture of our bodies is so thoroughly sound that when we are well we cannot easily fall ill except through extraordinary excess or infectious air or some other external cause.

Contrarily, fear or expectation of illness can be a self-fulfilling prophecy: there are 'people who are convinced by an astrologer or doctor that they must die at a certain time, and for this reason alone fall ill, and frequently even die'. Descartes said that he had personally seen that happen to several people. ${ }^{65}$

The next year, Descartes was plainly concerned about Elizabeth's continuing health anxieties. He told her what the remedy was; he assured her that he had taken it himself and that it worked; and, as her philosophical master, he told her why it worked in terms particular to his system. The therapy was 'so far as possible to distract our imagination and senses from [sources of distress], and when obliged by prudence to consider them to do so with our intellect alone'. Descartes himself had 'found by experience' that cheering up had 'cured an illness almost exactly the same as hers, and perhaps even more dangerous'. This was the 'dry cough and pale colour' he had inherited from his mother. But early on he recognized and reflected upon his own 'inclination to look at things from the most favourable angle and to make my principal happiness depend upon myself alone, and I believe that this inclination caused the indisposition, which was almost part of my nature, gradually to disappear completely ${ }^{6}{ }^{66}$ Descartes, acting as his own physician and moral counsellor, had cured himself of a condition which was, for all practical purposes, part of his innate constitution. He had changed his nature by successive rational acts of will. ${ }^{67}$

The way in which you could cure yourself by avoiding sadness lies at the heart of Descartes's physiology and of his medically consequential system for understanding the relations between body and mind. Sadness (and its opposite, joy) - like wonder, love, hatred and desire - was understood as a passion of the soul. The passions, for Descartes, are those thoughts (emotions, sensations, or perceptions) ' which are ... aroused in the soul by cerebral impressions alone, without the concurrence of its will, and therefore without any action of the soul itself; for whatever is not an action is a passion'. Commonly,

65 Letter from Descartes to Princess Elizabeth, 8 July 1644, in PWD, iii, 237.

66 Letter from Descartes to Princess Elizabeth, May or June 1645, in PWD, iii, 249-51.

67 Both ancient (Galenic) and early modern medical thought did in fact accept the possibility that habit might gradually change innate temperament; see, for example, Joubert, op. cit. (47), 43, and [Thomas Tryon], The Way of Health, Long Life and Happiness, or, a Discourse of Temperance..., London, 1683, 19. The author of the article on the non-naturals in the Encyclopédie agreed: see Emch-Dériaz, op. cit. (58), 138-9. So the proverbial 'habit is a second nature' can be understood to express the view that habit can give you another nature, not just the notion that habit is almost as strong as innate endowment. For early modern Stoicism and the management of the passions, see Dear, op. cit. (36), 68-72. 
however, the term was restricted to thoughts caused by some particular agitation of the spirits. ${ }^{68}$ The soul could be made sad by external influences. Descartes's account of how this happened was similar to his theory of sensation in general: the scenes and objects that make one sad cause motions on the body's surface - in the case of saddening visual scenes, motions on the eye and in the optic nerve. These stimulate motions of the animal spirits in the nerves, which motions are immediately transferred to the brain, and thence to the cavities in which the pineal gland is delicately suspended. The consequent movement of the gland is the cause of a sensory perception or of the emotion of sadness in the soul. The bodily feeling of sadness is caused by the body $\rightarrow$ brain $\rightarrow$ soul traffic flowing in the reverse direction: the soul's sadness is communicated via the animal spirits in the nerves to the heart, and thence to the different organs and muscles involved in the total bodily experience we call 'feeling sad'.

Externally caused sadness imprints itself on the brain, storing up perceptions and emotions to be retrieved as the soul wills. If the soul decides to summon up and dwell upon sad thoughts, the whole physiological system involved in the original, externally caused experience of sadness will again be put into play, internal causes now acting as effectively as the original external causes. Conversely, if the soul decides not to summon up sad thoughts and rather to retrieve joyful thoughts, the corresponding physiological processes will be suppressed and activated. And, of course, the soul can decide whether or not to put itself in a position where external sources of sadness are likely to occur, say by deciding not to read a sad book. The passions were thus open to volitional management: they were not, as in the Stoic vision, to be denied; they were to be disciplined and rightly directed. ${ }^{69}$

Canonical history of philosophy correctly identifies Descartes as the most systematic dualist of the Scientific Revolution: the ontological distinction between soul and body in Cartesian metaphysical writings is, of course, explicit and repeated. Descartes never abandoned that dualism nor did he ever reflectively compromise it. Nevertheless, were one so inclined, it would not be a difficult matter to infer from his actual medical practice a quite different unarticulated metaphysics. It is not just that Descartes's medicine was psychosomatic (or somatopsychic): this is an accepted, and a plausible, thing for historians to say about Cartesian thinking on such matters. ${ }^{70}$ Its plausibility proceeds from the intensity of the transactions Descartes's medical practice posits between material body and incorporeal soul. In these connections, interaction is so intense and consequential that ontological integrity is blurred. Susan James's recent study of the emotions in early modern

68 Letter from Descartes to Princess Elizabeth, 6 October 1645, in PWD, iii, 270; also Descartes, Passions, op. cit. (24), 338-9; and, for the most philosophically sensitive treatment of Descartes on the passions, S. James, Passion and Action: The Emotions in Seventeenth-Century Philosophy, Oxford, 1997, 92-100. The summary below closely follows James. See also idem, 'Reason, the passions, and the good life', in D. Garber and M. Ayers (eds.), The Cambridge History of Seventeenth-Century Philosophy, 2 vols., Cambridge, 1998, ii, 1358-96; idem, 'Explaining the passions: passions, desires, and the explanation of action', in S. Gaukroger (ed.), The Soft Underbelly of Reason: The Passions in the Seventeenth Century, London, 1998, 17-33.

69 Dear, op. cit. (36), 68-9.

70 Gaukroger (op. cit. (17), 388) interestingly suggests a shift occurring around the time of his correspondence with Princess Elizabeth 'from a somatopsychic account, in which the influence of bodily dispositions on the state of the soul is stressed, to a psychosomatic account in which are stressed the effects of the soul on bodily dispositions'. 
philosophy is a brilliant provocation to recognize the plausibility of a case for Descartes as anti-dualist, and a key passage merits extended quotation:

The thorough-going interconnection between body and soul therefore ensures that both changes in our bodily states and the patterns of our own thoughts give rise to passion. Throughout our lives, we are subject to delicately inflected and ever-changing emotions which direct and redirect our actions and are a central feature of our experience. The capacity of the passions to stream across the line between body and soul is matched by their capacity to cross the boundary around the body. By virtue of our passions, our thoughts are enormously sensitive to the states of our bodies, which have their own economies of normal and abnormal motions. Physical disease is accompanied by emotional disturbance, and a multitude of transitions in the temperature and pace of the blood coming from the various bodily organs cause a succession of passions, like clouds. Furthermore, we are continually affected by the world around us and respond emotionally to other people, their gestures, conversations, the books we read, the weather, music, the buildings we inhabit, and a thousand things besides. The fact that so many emotions pass through our porous outer skins ensures that our emotional life is constant and various, often more so than we realize. It serves not only to protect us from harm, but also to connect us to the material realm beyond our bodies.

Note how, in suggesting 'that the body thinks, and that among its thoughts are the passions', James naturally finds herself in the domain of health and disease, their practical understanding and management. ${ }^{71}$ The passions are systemic: having a sensation of sadness involves the soul and all the organs of the body that might be pertinent to their experience: the heaviness or heat of the heart, the sensation of sluggishness arising from the composition of the blood, and the condition of the spleen. Because of the systemic interaction between the soul and the body's solids and fluids, you could not only cure yourself by the rational management of thought, you could also cure yourself by the rational management of the other non-naturals. Diet mattered: aliment was the basis for all bodily constituents, including spirits. ${ }^{72}$ Airs and waters mattered, for example as they bore upon the composition and consistency of the blood: when the blood was in a fine and thin condition, joy was a likely consequence, and when it was too thick and sluggish its movement in the heart tended to produce sadness. Taking the Spa waters (and very judicious phlebotomy) might achieve that thinness, while dry air rendered the blood 'more subtle'. ${ }^{73}$ Sleeping and waking mattered: sleep allows the blood to refresh the brain substance, making it more responsive to the movement of spirits. ${ }^{74}$ And the active control of the passions mattered a great deal. (Recall that Descartes's theory of the passions developed in a specifically therapeutic medical context: Elizabeth complained about her state of health and Descartes offered medical advice.) The passions, after all, counted as one of the traditional non-naturals. The non-naturals were customarily identified as those things bearing upon the condition of our bodies that indeed were under our volitional

71 James, Passion and Action, op. cit. (68), 106-8 (my emphasis); A. O. Rorty, 'Descartes on thinking with the body', in Cottingham (ed.), op. cit. (17), 371-92; and Cottingham, op. cit. (1), 87-96.

72 Descartes, Treatise, op. cit. (22), 5-10, 17-19.

73 Descartes, Treatise, op. cit. (22), 70 ('when the blood that goes into the heart is more pure and subtle and is kindled more easily than usual, this arranges the little nerve that is there in the manner that is required to cause the sensation of joy'), and 111 (for dry air); letter from Descartes to Princess Elizabeth, May or June 1645, in PWD, iii, 250; Descartes, Principles, op. cit. (25), 280-1.

74 Descartes, Treatise, op. cit. (22), 108-12. 
control. And so Descartes, who started out by defining the passions as those things that were not volitional actions, ended up treating them in a therapeutic context in just the same way as the Galenists - something about which you could give medical advice, expecting that the prudent person would rationally act upon it.

\section{Custom and reason in Descartes's medical practice}

So, if Descartes were your doctor, this is the sort of advice you would get:

* First of all, once you have got a sufficient stock of experience with your own body, reflect upon and trust that experience, and do not be led by medical experts whose knowledge of your body is manifestly inferior to your own.

Within the terms of that general restriction, some robust sorts of advice included:

* Observe dietary moderation: be neither an ascetic nor a glutton. Go for a high-fibre diet: more vegetables than meat; avoid very spicy and salty foods. Do not drink too much. Variety of foods is good. Soup is very good.

* On the whole, let your appetites be your guide. Your body is probably telling you something; listen to it.

* Take exercise (and, by implication, venery) in moderation.

* Get plenty of bed-rest, and do whatever you know works best for you to secure a dreamless sleep. Don't get up from your bed too suddenly, and don't try to think too hard for long periods or at times that might interfere with your sleep.

* Don't let yourself be browbeaten into acceding to physicians' fashion for heroic bloodletting in particular or for any extreme or bizarre treatments in general. If you have to be bled to thin the blood, let it be in moderation and at the right times of year. Take great care with newfangled drugs, especially those whose composition is uncertain or known to be related to things that can harm people.

* And, above all, cheer up: avoid thinking about things that make you distressed; dwell on pleasant objects and memories; look on the bright side of life.

When the rationalist rubber hit the road - as he reckoned it ought to do - this is what Descartes's revolution in philosophy came down to. He said that he would reform philosophy on foundations wholly new, rejecting everything that he had been taught in the schools, and he said that practical effects on human health and longevity were among the principal aims of his philosophical career. Yet the medical advice he offered and took was wholly recognizable as belonging to long-standing and approved traditions of regimen and dietetics. It is quite true that the medical advice I have retrieved here derives overwhelmingly from personal communications rather than from published texts, but this is just the form in which Descartes chose to proffer practical advice. His texts as well as his informal communications generated expectations of radically new and powerfully medical practice, even suggesting that he already possessed elements of this practice. So it is pertinent to see what Descartes's practice consisted of - not as it might have been had he lived long enough to perfect his system, but as it actually was. In his own terms, it is a legitimate question to ask. What were the dietetics and the therapies of Reason?

In the main, it was the kind of advice you might give if you were an orthodox early modern Galenic physician. Even the scepticism about medical expertise-which, in 
Descartes's case, was very probably part of his proprietary challenge to scholasticism - resonates with the sort of scepticism that was broadly expressed in civic circles, and which, indeed, was elaborated by the great anti-rationalist Montaigne. ${ }^{75}$ Much of what Descartes counselled can be found in standard sixteenth- and seventeenth-century advice manuals, and, indeed, in the early twelfth-century Salernitan verses, the Regimen Sanitatis Salernitanum, endlessly reprinted, circulated and translated through the early modern period and beyond: 'Use three Physicians still; first Doctor Quiet, Next Doctor Merryman, and Doctor Dyet. ${ }^{76}$ The injunctions to 'know yourself' and to 'avoid excess' were carved on Apollo's temple at Delphi: they are not only central to the art of hygiene; they are its historical origins. Descartes's free and easy attitude towards the appetites in sickness is a version of what was known as the Rule of Celsus: the rule of no rule, the view that a healthy man should not enslave himself to any particular rule or system, that he should do whatever it is customary to do and subject himself to the varieties and vicissitudes of the life that was customary for people of his sort. ${ }^{77}$ The foolishness of the view that there was one right global rule for health followed from an appreciation of constitutional individuality that was also standard in traditional medicine: you should be your own physician, and you should find out what worked best for you, because no one else was just like you. Medicine, if it worked at all, worked upon idiosyncratic individual bodies.

The dependence of bodily health upon states of mind was likewise wholly familiar from traditional medical advice. Disease was understood to be the result of disorder and excess of any kind, disrupting the balance of the humours, obstructing their flow, and producing putrefaction and corruption. Physiological conditions could, as a matter of course, have psychological causes. Maintaining a healthy frame of mind was of vital importance to bodily health, and I have already noted that the passions counted among the non-naturals of Galenic medicine, their management understood to be as important to bodily well-being as food, drink and exercise. Indeed, the precise physiological effects of the passions were

75 Michel Eyquem de Montaigne, The Complete Essays of Montaigne, (trans. D. M. Frame), Stanford, CA, 1965 (originally published 1580-8), especially 'Of experience'. See, for example, the similarity between Montaigne's view of the appetites in sickness and views Descartes expressed in his conversation with Burman: 'Both in health and in sickness I have readily let myself follow my urgent appetites. I give great authority to my desires and inclinations' (ibid., 832). See also M. Brunyate, 'Montaigne and medicine', in K. Cameron (ed.), Montaigne and His Age, Exeter, 1981, 27-38, and, for general remarks on the conservatism of medical practice against the background of change in medical theory, see J. Henry, 'Doctors and healers: popular culture and the medical profession', in S. Pumfrey, P. L. Rossi and M. Slawinski (eds.), Science, Culture and Popular Belief in Renaissance Europe, Manchester, 1991, 191-221, especially 211-12: 'the mechanical philosophy made no significant impact on the practice of medicine'.

76 See e.g. H. E. Sigerist, Landmarks in the History of Hygiene, London, 1956, Chapter 2. The most influential English version in this period was Sir John Harington's The English Mans Doctor. Or the Schoole of Salerne, London, 1607. The quotation is from Sir John Harington, The School of Salernum: Regimen Sanitatis Salerni, Salerno, 1957, 22. For the proverbial element in early modern medical culture, see also Henry, op. cit. (75), 198-201, and Shapin op. cit. (58).

77 For the original, see Aulus fnotelius Celsus, De medicina, (trans. W. G. Spencer), 3 vols., Cambridge, Mass., 1960, i , 43 (Book I, i); also 57. Celsus probably lived in Tiberius' reign, the same emperor whose opinion that every man should be his own physician Descartes so much liked; cf. Plutarch: 'A diet which is very exact and precisely according to rule puts one's body both in fear and danger' (Plutarch, 'Rules for the preservation of health', in idem, Plutarch's Lives and Miscellanies (ed. A. H. Clough and W. W. Goodwin), 5 vols., New York, 1905, i, 251-79, 263). For many early modern endorsements of the Rule of Celsus, see Shapin, op. cit. (58). 
even identified in some popular medical texts of the sixteenth century: irritability might show up in the composition of the blood. ${ }^{78}$ The notion that a healthy body was in causal interaction with a healthy mind was proverbial: you did not have to know Juvenal's mens sana in corpore sano to be exposed to a folk version of the same view, while the moral importance of managing the passions was an article of Stoic conceptions of virtue and gentility that were widely influential in early modern civic circles. ${ }^{79}$

\section{Curing or enduring?}

So the practical medical advice that was advertised as issuing from Descartes's radical reform of philosophy was not itself at all radical. Nor was Descartes's confidence unalloyed in the ability of his rational reform to deliver the promised medical goods. Against the general background of boasts, promises and dreams, there was an undercurrent of doubt, resignation and reconciliation to inevitable fate. Even in the hubristic Discourse, Descartes said that he was reluctant to 'commit myself in the eyes of the public by making any promise that I am not sure of fulfilling, ${ }^{80}$ In the Principles, he expressed confidence that he had already established true philosophical principles, but that 'many centuries may pass before all the truths that can be deduced from these principles are actually so deduced'. ${ }^{81}$ When, in 1639, Descartes told Mersenne that he could already explain everything about the animal frame in detail and by natural causes, he confessed,

But for all that I do not yet know enough to be able to heal even a fever. Because I claim to know only animal in general, which is not subject to fevers, and not yet man in particular, who is. ${ }^{82}$

Nor did Descartes neglect formally to give providence its due. Quite possibly, Father Mersenne brought out the pious and the lugubrious side of him, but, in the same letter in which Descartes told him that he was very well and looked forward to a long life, he also acknowledged Divine pleasure and a traditional role of philosophy in counselling the wise man that, as the proverb says, what can't be cured must be endured:

Should God not grant me the knowledge to avoid the discomforts of old age, I hope he will at least grant me a long enough life and the leisure to endure them. Yet all depends upon his providence... One of the main points in my own ethical code is to love life without fearing death. ${ }^{83}$

78 P. Slack, 'Mirrors of health and treasures of poor men: the use of the vernacular medical literature of Tudor England', in C. Webster (ed.), Health, Medicine and Mortality in the Sixteenth Century, Cambridge, 1979, 237-73, 268.

79 A. Taylor, The Proverb, Berlin, 1985 (originally published 1931), 121-9; Dear, op. cit. (36); Baillet, op. cit. (19), 18-19, 59 (for Descartes's refusal to be 'a Slave' to passions, and how he overcame a youthful addiction to gambling).

80 Descartes, Discourse, op. cit. (15), 151.

81 Descartes, Principles, op. cit. (25), 189.

82 Letter from Descartes to Mersenne, 20 February 1639, in PWD, iii, 135.

83 Letter from Descartes to Mersenne, 9 January 1639, in PWD, iii, 131. In these connections, providence and the 'grace of God' were repeatedly invoked, and Descartes fell in with traditional Renaissance and early modern medical sensibilities about the complicated relationships between, on the one hand, using one's best efforts to maintain health and extend life and, on the other, acknowledging the limits to these efforts set by God's will and plan: see on this point Joubert, op. cit. (47), 41-3. 
In 1646 he told his friend Chanut that he had more success using physics to ground ethics than to ground medicine:

Indeed I have found it easier to reach satisfactory conclusions on [moral philosophy] than on many others concerning medicine, on which I have spent much more time. So instead of finding ways to preserve life, I have found another, much easier and surer way, which is not to fear death. But this does not depress me, as it commonly depresses those whose wisdom is drawn entirely from the teaching of others, and rests on foundations which depend only on human prudence and authority. ${ }^{84}$

Descartes had his occasional dark night of the soul, but these eruptions of resigned pathos are a counterpoint to the medical optimism that ran through his entire philosophical career. $^{85}$

Descartes understood, or at least intermittently appreciated, the hybrid status of medicine: as a science and as an art. If the object of medical science is body in general, the object of medical art is this particular ailing body. That is just the distinction Descartes recognized when he lamented to Mersenne that he really did not even know how to cure a fever. What worked in and for an imagined body - 'a statue, an earthen machine' - might not work in and for your body, which was to be understood as the result of your innate constitution plus your total historical transactions with the environment and your history of managing those transactions, suffering from your particular sort of fever on a cold Monday morning in winter, living in a place with gross air.

The art (or practice) of medicine was, therefore, action under uncertainty. Just as you must act in society without having certain knowledge of consequences, so you must eat without knowing whether this particular food is wholesome or poisonous. Knowledge that foods of this general kind have been good for you is not certain knowledge that this particular dish will not kill you. ${ }^{86}$ As in ethics and social conduct, so in the art of medicine: if you must act under uncertainty, then your best guides are, indeed, custom and, one might say, common sense. So in the Discourse Descartes wholly acknowledged that scepticism and the demand for certainty were limited as practical matters. Since you had to act even when absolute certainty was not attained or attainable, you had, as a general matter, to

84 Letter from Descartes to Chanut, 15 June 1646, in PWD, iii, 289; cf. Baillet, op. cit. (19), 53.

85 Cf. Gaukroger's contention (op. cit. (17), 388) that the sentiments expressed to Chanut represent an intellectual 'shift' brought about by the reflections on which Descartes was engaged c. 1645-6 about 'the nature of the substantial union of mind and body'. The Preface to The Passions of the Soul (1649) was, however, a quite typical Cartesian expression of medical optimism.

86 This is Descartes's own example: letter from Descartes to Hyperaspistes, August 1641, in PWD, iii, 189-90. Roger French (op. cit. (27), 78-9) puts the point at issue well:

As a scientia, medicine is 'assent to the conclusion of a demonstrative syllogism' [here French is quoting Vopiscus-Fortunatus Plemp, Dutch medical professor and friend of Descartes], but its individuality and autonomy lie in the fact that it is also an art. In the art of medicine, the writ of the philosophers does not run. In the art of medicine, there are no rules for certain knowledge: as Galen says there is no sure way of telling a nephritic from a colic pain, nor how a medicine acts by its 'whole substance'. As Celsus says, in the art of medicine there are no sure precepts, as in other natural sciences and there are many possible conclusions (and, by implication, the accumulated experiential knowledge of the centuries is important). 
provide yourself with some maxims of prudent conduct, the first of which was to follow 'the laws and customs of my country'. ${ }^{87}$ And this is what Descartes's medical practice really amounted to. After the rationalist and revolutionary smoke clears, the hubristic modernist Descartes and the sceptical traditionalist Montaigne turn out to be as one on the issue of medical practice. Custom is a pretty good guide. Know yourself. Avoid extremes.

Modernist philosophical ambitions and rhetorical fanfares did not find it that easy to shift long-standing traditions of medical practice. And the reasons why these traditions were so durable are interestingly related to the grounds on which Descartes's rationally founded medical advice might enjoy whatever authority and credibility it had in his society. Regimen and dietetics - the management of the non-naturals - were central components of the medical art. But, looked at from another point of view, that management amounted to a substantial part of individuals' quotidian life and of the customs held in common by the community or at least Descartes's sector of it. The body of culture that told you where to live, what to eat, when to sleep and how to control your passions was wholly integrated into the practices of everyday living and into the everyday moral environment that allowed actions to be reliably accounted good or bad. It was not only good for you to follow medical advice counselling moderation; it was just good to do so. Correspondingly, your health could be read as evidence that you had followed a virtuous course of conduct while your disease might be understood as the upshot of intemperance and viciousness. As Temkin sums up the Galenic hygienic tradition, 'A healthy life is a moral obligation... Health ... becomes a responsibility and disease a matter for possible moral reflection' ${ }^{88}$ That state of affairs was still firmly in place in the Renaissance and early modern period. Popular medical texts in the sixteenth and seventeenth centuries (and beyond) articulated moral and social norms as they advised how to live a healthy life and how to cure disease. ${ }^{89}$ That is why those traditions of medical practice were so resistant to change: revolutionary change in these practices would be just as difficult to achieve as social and cultural revolution.

But, as we have seen, Descartes did not challenge the practices of traditional medical art in any significant way. Belonging to the domain of judgement under uncertainty, those percepts and maxims were pretty good guides to follow until the promised system of 'infallible demonstrations' was secured, or, put another way, until squadrons of pigs flew past his window in tight formation. In so far as Descartes's medical advice enjoyed local authority, that authority must have been substantially borrowed from the same medical tradition that, as a philosopher, he affected to despise. We are now on stage again with Molière's Le Malade imaginaire. Previously you were to control the passion of anger because it unbalanced the humours. Now reference to humours was deemed unintelligible: instead you were to control the passion of anger because it had a certain effect on the animal spirits which, when communicated to the heart, affected the size of its pores, which

87 Descartes, Discourse, op. cit. (15), 122.

88 O. Temkin, Galenism: Rise and Decline of a Medical Philosophy, Ithaca, 1973, 39-40.

89 Slack, op. cit. (78), 271-2; also A. Macfarlane, The Family Life of Ralph Josselin, a Seventeenth-Century Clergyman: An Essay in Historical Anthropology, Cambridge, 1970, especially 173-6; K. Thomas, 'Health and morality in early modern England', in A. M. Brandt and P. Rozin (eds.), Morality and Health, New York, 1997, 15-34, esp. 20-4; Shapin op. cit. (58). 
unbalanced the consistency of the blood. ${ }^{90}$ Mechanical philosophy, like its Aristotelian and Galenist predecessors, provided a language for talking about human beings and their vicissitudes in relation to the rest of the universe. There were all kinds of reasons why certain people might want such a language, and why certain people might find a mechanical language preferable to, even more intelligible than, alternatives. ${ }^{91}$ But a unique causal relationship to new and effective medical interventions is not one of them.

90 For a brilliant survey of this general tendency in seventeenth-century mechanical philosophy, see A. Gabbey, 'The mechanical philosophy and its problems: mechanical explanations, impenetrability, and perpetual motion', in J. C. Pitt (ed.), Change and Progress in Modern Science, Dordrecht, 1985, 9-84, especially 10-12. T. S. Hall shows that these kinds of apparently revolutionary but practically insubstantial transformations are also at the heart of Descartes's physiology. Descartes claimed to reject Galen while recasting many Galenic concepts in the vocabulary of Cartesian physics: see Hall's notes to the text of Descartes's Treatise, op. cit. (22), e.g. nn. 13, 21, 35, 85; see also Hatfield, op. cit. (29), 341-4; and, for overall continuities between Cartesian thought and tradition, E. Gilson, Etudes sur le rôle de la pensée médiévale dans la formation du système cartésien, 4th edn., Paris, 1975, and D. Des Chene, Physiologia: Natural Philosophy in Late Aristotelian and Cartesian Thought, Ithaca, 1996.

91 For attempts at genuinely historical explanation of mechanical intelligibility, see Dear, op. cit. (36). 